\title{
Hubungan Riwayat Pemberian ASI dengan Kecenderungan Attention Deficit Hyperactivity Disorder (ADHD) pada Siswa SD di Kota Padang
}

\author{
Risa Firka1 ${ }^{1}$ Eva Chundrayetti², Yustini Alioes ${ }^{3}$
}

\begin{abstract}
Abstrak
ADHD (Attention Deficit Hyperactivity Disorder) merupakan masalah perilaku di masa kecil yang dapat berlanjut hingga dewasa. Pemberian ASI dapat menurunkan risiko terjadinya ADHD pada anak. Tujuan: Mengetahui hubungan antara riwayat pemberian ASI dengan kecenderungan attention deficit hyperactivity disorder (ADHD) pada siswa SD di Kota Padang. Metode: Jenis penelitian ini adalah analitik dengan desain cross sectional. Responden penelitian adalah guru dan ibu dari siswa SD di Kelurahan Ulak Karang Selatan yang berumur 7 sampai 12 tahun sebanyak 134 orang. Pengambilan sampel dilakukan dengan teknik consecutive sampling. Instrumen penelitian ini menggunakan kuesioner riwayat pemberian ASI dan Conner's Abbreviated Parent-Teacher Rating Scale. Data dianalisis menggunakan Chisquare test. Hasil: Terdapat 25 orang (18,7\%) yang cenderung ADHD dengan 18 orang (72,0\%) laki - laki dan usia terbanyak adalah 7 tahun (32,0). Cakupan ASI eksklusif didapatkan sebesar 71 orang (53,0\%). Terdapat 11 anak $(15,5 \%)$ dengan kecenderungan ADHD pada riwayat pemberian ASI eksklusif dan 14 anak (22,2\%) ASI tidak eksklusif. Tidak terdapat hubungan secara signifikan antara riwayat pemberian ASI dengan kecenderungan ADHD pada siswa SD di Kota Padang $(p=0,318)$. Simpulan: Tidak ada hubungan antara riwayat pemberian ASI dengan kecenderungan ADHD.
\end{abstract}

Kata kunci: ADHD, ASI eksklusif, anak

\begin{abstract}
$A D H D$ (attention deficit hyperactivity disorder) is a behavioral problem that affects in childhood that can continue until adulthood. Breastfeeding can lower the risk of developing ADHD in children. Objectives: To evaluated the association between breastfeeding history and ADHD tendency of primary school students in Padang city. Methods: A cross sectional design was used in this analytic research. The research respondents were teachers and mothers of primary school students in Ulak Karang Selatan village, aged from seven years old until twelve years old around one hundred thirty four people. Sampling was done by consecutive sampling technique. Respondent were assessed by using the breastfeeding history questionnaire and the Conner's Abbreviated Parent-Teacher Rating Scale. Data were analyzed by using Chi Square Test. Results: Twenty five people (18.7\%) who had ADHD tendency with eighteen people (72.0\%) were male and the highest age for ADHD was seven years old (32.0\%). Exclusive coverage is gained by seventy one people (53,0\%). Total of eleven people (15.5\%) ADHD tendency children with exclusive breastfeeding history and fourteen people (22.2\%) without exclusive breastfeeding. There were no significant association between breastfeeding history and $A D H D$ tendency of primary school students in Padang city ( $p=0.381)$. Conclusion: There is no association a history of breastfeeding with ADHD tendency.
\end{abstract}

Keywords: $A D H D$, exclusive breastfeeding, children

Affiliasi penulis: 1. Prodi Pendidikan Dokter,Fakultas Kedokteran, Universitas Andalas, Padang, Indonesia. 2. Bagian IImu Kesehatan Anak, Fakultas Kedokteran, Universitas Andalas, Padang, Indonesia. 3. Bagian Biokimia, Fakultas Kedokteran, Universitas Andalas, Padang, Indonesia.
Korespondensi: Eva Chundrayetti, Email: echundrayetti@yahoo.com Telp: 082285805833 


\section{PENDAHULUAN}

Gangguan Pemusatan Perhatian dan Hiperaktivitas (GPPH) atau dikenal dengan singkatan ADHD (Attention Deficit Hyperactivity Disorder) merupakan gangguan beragam dengan epidemiologi dan etiologi yang kompleks. ADHD merupakan gangguan fungsi otak yang bersifat kronis yang dapat mengakibatkan penurunan fungsi kognitif pada anak. ${ }^{1}$ Gejala timbulnya ADHD dimulai pada masa sekolah yaitu pada usia 7 sampai 12 tahun. Informasi mengenai ADHD harus diperoleh dari dua orang yang berbeda yaitu seperti orang tua, guru, atau orang dewasa lainnya yang berinteraksi lama dengan anak. ${ }^{2}$ Penelitian menunjukkan bahwa sejumlah anak yang didiagnosis ADHD akan terus mengalami gejala sampai dewasa yang berdampak pada fungsi pribadi, akademik, keluarga, dan kehidupan bermasyarakat. ${ }^{3}$

Ada tiga gejala utama dari ADHD yaitu inatensi, hiperaktivitas, dan impulsivitas. Gejala tersebut ditandai dengan kurangnya perhatian, hilang minat saat mengerjakan suatu tugas atau kegiatan, mudah terganggu dan pelupa, kesulitan saat mengatur kegiatan, tampak anak dengan gerakan motorik yang berlebihan, tampak tidak sabar, dan sering tidak dapat dicegah dalam situasi sosial. Mereka mungkin merasa sulit untuk menunggu giliran mereka, mengganggu kegiatan orang lain atau melontarkan jawaban atas sebuah pertanyaan sebelum diselesaikan. Anak ADHD cenderung dianggap mengganggu orang di sekitar mereka. ${ }^{3}$ ADHD juga dapat mempengaruhi prestasi dari belajar anak seperti kesulitan membaca, mengeja, berhitung dan menulis. Stres emosional juga dapat dialami oleh anak jika mendapat celaan dari orang tua, guru, dan teman sebaya sehingga bisa menyebabkan depresi dikemudian hari. ${ }^{4}$ Ini adalah alasan utama orang tua untuk membawa anaknya untuk berobat kerumah sakit. ${ }^{1}$

Prevelensi kejadian ADHD di dunia sangat bervariasi, diperkirakan untuk kejadian pada anak dan remaja sekitar 5,9 - 7,1\% dengan temuan bahwa tingkat diagnosis telah meningkat dalam beberapa tahun ini. Prevelensi ADHD secara global antara usia 5 - 19 tahun dengan puncak pada usia 9 tahun. ADHD masih kurang terdiagnosis di beberapa negara terutama pada anak perempuan dan anak - anak yang lebih tua. ${ }^{5}$ Survei di AS menunjukkan bahwa persentase anak berumur $4-17$ tahun dengan diagnosis ADHD meningkat sebesar $21,8 \%$ dari tahun 2003 hingga 2007. Studi lain menggunakan catatan medis di California melaporkan peningkatan 24\% dalam kejadian ADHD yang didiagnosis dokter pada anak usia 5 hingga 11 tahun dari tahun 2001 sampai 2010. ${ }^{6}$ Prevelensi ADHD di Indonesia masih sedikit. Berdasarkan penelitian yang dilakukan di Semarang pada tahun 2016 sampai 2017 pada anak usia $4-6$ tahun didapatkan angka prevelensi sebesar 15,5\% dengan menggunakan kuesioner SPPAHI. ${ }^{7}$ Pada tahun 2013, penelitian yang dilakukan terhadap siswa dan siswi sekolah dasar di Kecamatan Padang Timur didapatkan prevelensi sebesar $8 \%$ dan perbandingan laki-laki dengan perempuan 2:1 dengan menggunakan kuesioner conner's abbreviated teacher - parent rating scale. Gejala ADHD terbanyak ditunjukkan pada usia $11-13$ tahun. $^{8}$

Penyebab dari ADHD tidak diketahui secara pasti. Diyakini bahwa faktor genetik dan lingkungan berperan penting terhadap kejadian ADHD. ${ }^{4}$ Beberapa penelitian juga menyebutkan kelahiran prematur, BBLR, ataupun ibu yang merokok selama kehamilan juga merupakan faktor penyebab ADHD. ${ }^{9}$ Nutrisi merupakan salah satu dukungan paling penting untuk perkembangan saraf otak. Nutrisi yang tidak optimal dapat menyebabkan adaptasi yang dapat merusak perkembangan otak anak dan juga berpengaruh terhadap saluran cerna. ${ }^{10}$ Pemberian nutrisi yang tidak adekuat dapat memodulasi komposisi dan fungsi mikrobiota usus yang berperan penting dalam perkembangan saraf otak sehingga dapat mempengaruhi perkembangan ADHD. Perubahan komposisi dan fungsi mikrobiota menyebabkan terganggunya permeabilitas usus sehinggga menyebabkan migrasi bakteri ke siskulasi sitemik. Ini akan menimbulkan peradangan sistemik yang mengganggu sawar darah - otak dan menyebabkan neuron berinflamasi sehingga menyebabkan masalah kesehatan mental salah satunya ADHD. ${ }^{11}$ Penelitian menyebutkan bahwa air susu ibu (ASI) dapat mengurangi berbagai penyakit infeksi dan non infeksi. ASI juga dapat meningkatkan kecerdasan dan menurunkan risiko masalah perilaku seperti ADHD. ${ }^{12}$ 
Air Susu Ibu (ASI) adalah sumber nutrisi terbaik bagi bayi karena komposisinya yang unik. ASI terdiri dari lemak dan air dalam larutan protein, laktosa, dan garam organik yang di sekresi kelenjar mamae yang penting diberikan pada bayi baru lahir. ASI mengandung faktor protektif dan nutrien yang mempengaruhi perkembangan fisik dan mental anak sehingga dapat terhindar dari serangan berbagai penyakit. ASI mengandung asam lemak esensial, vitamin, mineral, dan asam amino yang penting untuk peningkatan fungsi kognitif, fungsi bahasa, dan perkembangan neurologis. ${ }^{13}$ Salah satu asam lemak yang penting untuk perkembangan otak anak adalah lemak omega 3 Decosahexaenoic Acid (DHA) yang memiliki peran penting dalam perkembangan saraf, transmisi neurotransmitter, dan ekspresi genetik. Anak yang diberi ASI menunjukkan perkembangan kognitif yaitu memiliki kecerdesan dengan IQ di atas 8 poin dari pada anak yang diberi susu formula. ${ }^{14}$ Menyusui selama 10 bulan/ lebih dapat mengurangi gejala internalisasi pada anak seperti gejala cemas, depresi, somatik bahkan ADHD. Anak yang di susui lebih dari 6 bulan memiliki skor test perkembangan kognitif yang lebih tinggi pada usia 10 tahun dibandingkan anak anak yang tidak mendapatkan ASI. ${ }^{15}$

Kementerian Kesehatan Republik Indonesia merekomendasikan pemberian ASI pada bayi selama 6 bulan (ASI eksklusif) dilanjutkan sampai 2 tahun dan diselingi MPASI (Makanan Pendamping Air Susu lbu) setelah bayi berumur 6 bulan. ${ }^{16}$ Hampir semua bayi yang disusui secara eksklusif selama 6 bulan pertama kehidupan mencapai pertumbuhan, perkembangan, dan kesehatan yang optimal. ${ }^{10}$ Pencapaian 6 bulan ASI eksklusif bergantung pada keberhasilan inisiasi dalam satu jam pertama. Penelitian menyatakan bahwa inisiasi dini dalam satu jam pertama dapat mencegah $22 \%$ kematian bayi dibawah umur satu bulan di negara-negara berkembang. ASI eksklusif selama 6 bulan pertama kehidupan, bersamaan dengan makanan pedamping ASI dan meneruskan ASI dari 6 bulan sampai 2 tahun, dapat mengurangi sedikitnya $20 \%$ kematian anak balita. ${ }^{16}$

Target cakupan Pemerintahan Indonesia terhadap pemberian air susu ibu (ASI) eksklusif sekitar $80 \%$, tetapi hasil survei baru menunjukkan cakupan ASI eksklusif baru mencapai $32 \%$ pada umur $0-6$ bulan pada tahun 2007 dan menjadi 42\% pada tahun 2012. Berdasarkan laporan dinas kesehatan provinsi cakupan pemberian ASI eksklusif rata-rata mencapai $54,3 \%$ dan di Sumatera Barat sendiri mencapai 68,9\% pada tahun 2013. ${ }^{16}$ Kota Padang sendiri cakupan masih berada pada angka 70,5\% dan belum mencapai angka nasional. Berdasarkan data dari dinas kesehatan Kota Padang dari tahun 2015 - 2017, salah satu daerah yang memiliki cakupan ASI eksklusif yang tinggi adalah Kelurahan Ulak Karang Selatan dengan persentase $90,96 \%, 90,2 \%$, dan $89,90 \% .^{17}$

Menyusui memiliki banyak manfaat untuk kesehatan ibu dan anak serta dapat meningkatan ikatan ibu-anak. ${ }^{13}$ Banyak faktor yang mempengaruhi kurangnya cakupan pemberian ASI eksklusif pada bayi. Beberapa diantaranya, tidak dilakukannya Inisiasi Menyusui Dini (IMD), usi ibu yang terlalu muda yaitu < 25 tahun, faktor kesehatan dan psikis ibu, tingkat pendididikan dan dukungan dari keluarga. ${ }^{18}$ Perkembangan zaman dan banyaknya lapangan pekerjaan menuntut ibu untuk meningkatkan status ekonomi sehingga banyak berada di luar rumah dan tidak sempat menyusui bayinya. ${ }^{19}$

\section{METODE}

Penelitian dilaksanakan pada sekolah dasar di Kelurahan Ulak Karang Selatan. Jenis penelitian ini adalah analitik dengan rancangan cross sectional yaitu dengan yaitu dengan observasi variabel - variabel yang diteliti pada suatu waktu tertentu. Variabel independennya adalah riwayat pemberian ASI dan variabel dependennya adalah ADHD. Penelitian dilakukan dari bulan September 2018 sampai Februari 2019 pada lbu siswa dan guru SD di Kelurahan Ulak Karang Selatan, Kota Padang.

Populasi pada penelitian ini adalah siswa SD di Kelurahan Ulak Karang Selatan Kota Padang yang berjumlah 1.579 orang siswa. Sampel penelitian ini sebesar 134 siswa SD yang memenuhi kriteria inklusi dan eksklusi. Kriteria inklusi : siswa SD yang berumur 7 sampai 12 tahun yang terpilih dalam penelitian, Ibu dari anak yang bersedia mengikuti penelitian dan menjawab pertanyaan dalam kuesioner, guru yang mengajar pada SD yang terpilih dalam penelitian, dan anak bertempat tinggal di Kelurahan Ulak Karang Selatan. Kriteria eksklusi: koresponden yang tidak 
hadir dalam penelitian dan menolak dan tidak bersedia mengikuti penelitian, anak yang ibu kandungnya sudah meninggal atau tidak tinggal serumah dengan ibu kandungnya, dan jumlah skor Conner's Abbreviated Parent-Teacher Rating scale yang salah satunya $\geq 15$ baik guru maupun ibu (meragukan). Sampel dihitung dengan menggunakan rumus:

$$
\mathrm{n}=\frac{\mathrm{z}^{2} \alpha \mathrm{pq}}{\mathrm{d}^{2}}
$$

Keterangan:

$\mathrm{n} \quad$ = jumlah sampel minimal

$Z^{2} \alpha=$ nilai distribusi normal baku (1.96)

$\mathrm{p}=$ porposi 0,08

$q=1-p$

d $=$ limit error, 0.05

Berdasarkan rumus di atas didapatkan jumlah sampel sebanyak 113 dan dengan memperhitungkan drop out sebesar $10 \%$ maka jumlah sampel yang terpilih adalah 124 orang. Teknik pengambilan sampel dengan consecutive sampling pada 6 sekolah dasar di Kelurahan Ulak Karang Selatan.

Pengumpulan data dengan menggunakan kuesioner yang di isi oleh responden. Terdapat dua kuesioner dalam penelitian ini, yaitu riwayat pemberian ASI dan Conner's Abbreviated Parent - Teacher Rating Scale. Kuesioner riwayat pemberian ASI yang diisi oleh ibu dan Conner's Abbreviated Parent Teacher Rating Scale yang diisi oleh ibu dan guru.

Data dianalisis secara statistik berdasarkan variabel yang dinilai menggunakan sistem komputerisasi yaitu analisis univariat dan bivariat. Analisis univariat digunakan untuk melihat distribusi frekuensi variabel independen dan variabel dependen. Analisis bivariat dilakukan untuk menganalisis ada atau tidaknya hubungan antara variabel independen dan variabel dependen. Hubungan dua variabel tersebut dianalisis dengan menggunakan uji Chisquare dan dikatakan bermakna bila nilai $p<0.05$.
HASIL

Penelitian ini dilakukan pada 6 sekolah dasar yang berada di Kelurahan Ulak Karang Selatan yaitu SDN 01 Ulak Karang Selatan, SDN 02 Ulak Karang Selatan, SDN 07 Ulak Karang Selatan, SDN 08 Ulak Karang Selatan, SDN 14 Belanti Barat, dan SD Alam Minangkabau pada tanggal 28 Januari sampai 15 Februari 2019. Berdasarkan 150 kuesioner yang dibagikan kepada responden, didapatkan 134 responden yang memenuhi kriteria inklusi dan tidak memenuhi kriteria eksklusi. Jumlah sampel pada penelitian ini telah mencukupi jumlah sampel minimal penelitian. Data hasil penelitian dikumpulkan dan dianalisis meliputi univariat dan analisis bivariat.

Tabel 1. Distribusi frekuensi karakteristik responden berdasarkan usia

\begin{tabular}{ccc}
\hline Usia (tahun) & $\mathbf{f}$ & $\%$ \\
\hline 7 & 23 & 17,2 \\
8 & 28 & 20,9 \\
9 & 24 & 17,9 \\
10 & 21 & 15,7 \\
11 & 20 & 14,9 \\
12 & 18 & 13,4 \\
\hline Total & 134 & 100,0 \\
\hline
\end{tabular}

Hasil analisis pada Tabel 1 menunjukkan bahwa paling banyak responden berusia 8 tahun yaitu 28 orang $(20,9 \%)$.

Tabel 2. Distribusi frekuensi karakteristik responden berdasarkan jenis kelamin

\begin{tabular}{lcc}
\hline Jenis Kelamin & $\mathbf{f}$ & $\%$ \\
\hline Laki - laki & 75 & 56,0 \\
Perempuan & 59 & 44,0 \\
\cline { 2 - 3 } Total & 134 & 100,0 \\
\hline
\end{tabular}

Hasil analisis Tabel 2 diatas menunjukkan dari 134 responden, jenis kelamin sebagian besar laki - laki yaitu 75 orang $(56,0 \%)$. 
Tabel 3. Distribusi kecenderungan ADHD berdasarkan usia

\begin{tabular}{|c|c|c|c|c|}
\hline \multirow{2}{*}{$\begin{array}{c}\text { Usia } \\
\text { (tahun) }\end{array}$} & \multicolumn{2}{|c|}{ Prilaku Anak } & \multirow{2}{*}{ f } & \multirow{2}{*}{$\%$} \\
\hline & Tidak ADHD & ADHD & & \\
\hline \multirow[t]{2}{*}{7} & 15 & 8 & \multirow{2}{*}{23} & \multirow{2}{*}{100,0} \\
\hline & $(65,2 \%)$ & $(34,8 \%)$ & & \\
\hline \multirow[t]{2}{*}{8} & 25 & 3 & \multirow{2}{*}{28} & \multirow{2}{*}{100,0} \\
\hline & $(89,3 \%)$ & $(10,7 \%)$ & & \\
\hline \multirow[t]{2}{*}{9} & 20 & 4 & \multirow{2}{*}{24} & \multirow{2}{*}{100,0} \\
\hline & $(83,3 \%)$ & $(16,7 \%)$ & & \\
\hline \multirow[t]{2}{*}{10} & 16 & 5 & \multirow{2}{*}{21} & \multirow{2}{*}{100,0} \\
\hline & $(76,2 \%)$ & $(23,8 \%)$ & & \\
\hline \multirow[t]{2}{*}{11} & 18 & 2 & \multirow{2}{*}{20} & \multirow{2}{*}{100,0} \\
\hline & $(90,0 \%)$ & $(10,0 \%)$ & & \\
\hline \multirow[t]{2}{*}{12} & 15 & 3 & \multirow{2}{*}{18} & \multirow{2}{*}{100,0} \\
\hline & $(83,3 \%)$ & $(16,7 \%)$ & & \\
\hline \multirow[t]{2}{*}{$\overline{\text { Total }}$} & 109 & 25 & \multirow{2}{*}{134} & \multirow{2}{*}{100,0} \\
\hline & $(81,3 \%)$ & $(18,7 \%)$ & & \\
\hline
\end{tabular}

Hasil analisis pada Tabel 3 menunjukkan bahwa paling banyak responden yang mengalami kecenderungan ADHD pada usia 7 tahun yaitu 8 orang $(34,8 \%)$.

Tabel 4. Distribusi kecenderungan ADHD berdasarkan jenis kelamin

\begin{tabular}{cccccc}
\hline \multirow{2}{*}{ Jenis Kelamin } & \multicolumn{3}{c}{ Prilaku Anak } & & \\
\cline { 2 - 4 } & $\begin{array}{c}\text { Tidak } \\
\text { ADHD }\end{array}$ & ADHD & & $\%$ \\
\hline $\mathrm{L}$ & 57 & 18 & 75 & 100,0 \\
& $(76,0 \%)$ & $(24,0 \%)$ & & \\
$\mathrm{P}$ & 52 & 7 & 59 & 100,0 \\
& $(88,1 \%)$ & $(11,9 \%)$ & & \\
\hline Total & 109 & 25 & 125 & 100,0 \\
\hline
\end{tabular}

Hasil analisis Tabel 4 diatas menunjukkan dari 134 responden, jenis kelamin yang mengalami kecenderungan ADHD sebagian besar adalah laki laki yaitu 18 orang $(24,0 \%)$.

Tabel 5. Distribusi cakupan pemberian ASI

\begin{tabular}{lcc}
\hline \multicolumn{1}{c}{ Variabel } & $\mathbf{f}$ & $\%$ \\
\hline -ASI Eksklusif & 71 & 53,0 \\
-Tidak ASI Eksklusif & 58 & 43,3 \\
-Tidak ASI & 5 & 3,7 \\
\hline \multicolumn{1}{c}{ Total } & 134 & 100,0 \\
\hline
\end{tabular}

Hasil analisis Tabel 5 menunjukkan bahwa distribusi cakupan ASI pada 134 responden terbanyak didapatkan pada ASI eksklusif 71 orang (53,0\%).

Tabel 6. Hubungan riwayat pemberian ASI dengan kecenderungan ADHD

\begin{tabular}{|c|c|c|c|c|c|c|c|}
\hline & \multicolumn{4}{|c|}{ Prilaku Anak } & \multirow{2}{*}{\multicolumn{2}{|c|}{ Total }} & \multirow{3}{*}{$p$} \\
\hline & \multicolumn{2}{|c|}{ Tidak ADHD } & \multicolumn{2}{|c|}{ ADHD } & & & \\
\hline & $f$ & $\%$ & $f$ & $\%$ & $f$ & $\%$ & \\
\hline ASIE & 60 & 84,5 & 11 & 15,5 & 71 & 100,0 & \\
\hline Tidak & 49 & 77,8 & 14 & 22,2 & 63 & 100,0 & 0,318 \\
\hline ASI E & & & & & & & \\
\hline Total & 109 & & 25 & & 125 & 100,0 & \\
\hline
\end{tabular}

Hasil analisis Tabel 6 menunjukkan bahwa 14 orang $(22,2 \%)$ anak dengan kecenderungan ADHD terjadi pada ibu yang tidak menyusui secara eksklusif.

Uji statistik Chi-square mendapatkan nilai $\mathrm{p}=$ 0,381 ( $p>0,05)$. Berdasarkan hasil tersebut dapat disimpulkan secara statistik bahwa tidak terdapat hubungan yang signifikan antara riwayat pemberian ASI dengan kecenderungan ADHD pada siswa SD di Kota Padang.

\section{PEMBAHASAN}

Penelitian ini dilakukan pada enam sekolah dasar yang terletak di kelurahan Ulak Karang Selatan Kecamatan Padang Utara yaitu SDN 01 Ulak Karang Selatan, SDN 02 Ulak Karang Selatan, SDN 07 Ulak Karang Selatan, SDN 08 Ulak Karang Selatan, SDN 14 Belanti Barat, dan SD Alam Minangkabau. Pemilihan sekolah berdasarkan dari tingginya cakupan ASI eksklusif di Ulak Karang. Pemilihan sekolah dasar negeri dan swasta adalah untuk alasan heterogenisasi sampel dan juga untuk menyingkirkan adanya kemungkinan gangguan lain yang dapat menyertai anak dengan ADHD seperti retardasi mental. Jumlah sampel pada penelitian ini 134 orang yang memenuhi kriteria inklusi dan eksklusi dan dibagi pada tiap sekolah berdasarkan jumlah total siswa.

Pada penelitian ini, responden sebanyak 134 orang dari umur 7 sampai 12 tahun. Ini sesuai dengan penelitian yang dilakukan oleh Novriana et al (2013) 
mengambil usia anak pada masa sekolah. ${ }^{8} \mathrm{Hal}$ ini juga sesuai dengan Saputro (2009) dengan pengambilan sampel adalah anak sekolah dasar di DKI Jakarta yang terdiri dari siswa kelas 1 sampai dengan kelas 6 dan dibagi atas kelompok ADHD dan kelompok normal. ${ }^{1}$ Data terbanyak didapatkan usia 8 tahun sebanyak 28 orang dan paling sedikit pada umur 12 tahun sebanyak 18 orang. Ketidakmerataan dalam pengambilan sampel disebabkan oleh ketidaksediaan beberapa guru dan lbu menjadi responden penelitian. Begitu juga dengan jenis kelamin laki - laki yang lebih banyak dari pada perempuan. Novriana (2013) juga memiliki sampel laki - laki yang lebih dari pada perempuan. ${ }^{8}$ Ini juga sama dengan yang dilakukan oleh Saputro (2009). ${ }^{1}$

Penelitian yang dilakukan terhadap 134 orang sampel, didapatkan prevelensi kecenderungan ADHD sebesar $18,7 \%$ atau sebenyak 25 orang siswa. Hal ini jauh meningkat dari yang telah diteliti di Semarang pada tahun 2018, kejadian ADHD sebanyak 11 orang (15,5\%) pada anak usia 4-6 tahun. Salah satu faktor umur mempengaruhi perbedaan hasil penelitian. ${ }^{7}$ Angka kisaran untuk Kota Padang hanya 6 orang (8\%) yang dilakukan pada siswa sekolah dasar pada tahun 2013 dengan pengambilan secara random. Sehingga, ada beberapa siswa yang kemungkinan ADHD tidak terambil sebagai sampel penelitian. ${ }^{8}$ Angka penelitian ini sedikit lebih kecil dari penelitian yang dilakukan pada sekolah dasar di DKI Jakarta yaitu $26,2 \%$. Pada penelitian ini didapatkan kejadian terbanyak pada usia 5-7 tahun (28,2\%) dengan menggunakan kuesioner SPPAHI yang disesuaikan dengan kultur budaya masyarakat Indonesia. Perbedaan angka ini diduga akibat perbedaan metode dan instrument. ${ }^{1}$

Diagnosis ADHD pada anak dan remaja di Amerika Serikat dari tahun 1997 - 2016 meningkat dari $6,1 \%$ menjadi $10,2 \%$. Pada tahun 2016, AS juga pernah melakukan penelitian pada anak usia $2-17$ tahun menderita ADHD sebesar 8,4\%. ${ }^{20}$ Prevalensi ADHD di beberapa wilayah di Italia berkisar antara $1,1 \%-16,7 \%$ pada responden yang berusia $5-17$ tahun. ${ }^{21}$ Penelitian yang dilakukan di Kairo terhadap siswa sekolah dasar didapatkan 10,3\% kasus berat, $5,7 \%$ kasus sedang, dan $83,9 \%$ kasus ringan. ${ }^{22}$ Perilaku ADHD pada siswa sekolah dasar di Arab Saudi sebesar 5\% pada Juli - November 2016 dengan prevelensi tertinggi di kelas 3 (usia 9 tahun) sebesar $7,1 \%$ dan terendah pada kelas 6 sebesar 3,4\%. ${ }^{23}$ Semua penelitian pada negara - negara tersebut mempunyai hasil yang lebih kecil dari penelitian ini diakibatkan perbedaan budaya dan penggunaan metode dan instrumen penelitian. Teridentifikasi usia siswa sekolah dasar yang mengalami kecenderungan ADHD sebagian besar berusia 7 tahun yaitu 8 orang dan paling rendah usia 12 tahun yaitu 2 orang. Hasil penelitian ini sesuai dengan literatur bahwa ADHD mulai tampak jelas saat memasuki usia sekolah atau usia 7 tahun. $^{2}$ Ini juga sesuai dengan penelitian yang dilakukan oleh Saputro (2009) menunjukkan bahwa prevalensi ADHD terbanyak berada pada umur 5- 7 tahun $(28,2 \%)$, umur $8-10$ tahun $(24,7 \%)$, dan umur 11-13 tahun (25,8\%). ${ }^{1}$ Hasil ini jauh berbeda dari penelitian Novriana (2013) yaitu kejadian ADHD tertinggi terjadi pada usia 11-13 tahun (50\%). Ini disebabkan karena perbedaan pengambilan sampel dalam penelitian, dimana pada penelitian Novriana (2013) pengambilan sampel secara random/ acak. ${ }^{8}$

Jenis kelamin yang menjadi mayoritas kejadian ADHD pada penelitian ini adalah laki - laki yaitu 18 orang dibandingkan perempuan yaitu 7 orang yaitu 2,5: 1. Hasil penelitian ini sesuai dengan penelitian Novriana (2013) yaitu perbandingan kejadian ADHD antara laki - laki dan perempuan berkisar $2: 1 .^{8}$ Penelitian ini juga sesuai dengan yang dilakukan oleh Saputro (2009). ${ }^{1}$ Pada Kaplan disebutkan bahwa kejadian ADHD berkisar pada $3-5: 1 .^{28} \mathrm{Hal}$ ini diakibatkan pada laki - laki yang bersifat lebih agresif dari pada perempuan sehingga untuk gejala pada lakilaki lebih mudah ditemui. ${ }^{24}$

Hasil penelitian ini menunjukkan bahwa skor cakupan ASI eksklusif pada sekolah dasar di Kelurahan Ulak Karang Selatan hanya sebesar 53,0\% sedangkan untuk cakupan ASI yang terdata di puskesmas Ulak Karang sebesar $89,90 \%$ dan Kota Padang 72,5\% pada tahun 2017. ${ }^{17}$ Hasil ini masih lebih rendah dari kelurahan dan Kota Padang. Penelitian ini tidak sebanding dengan Indonesia sendiri pada tahun 2017 cakupan ASI eksklusif secara nasional sebesar 35,7\% dan lebih tinggi dari angka nasional. Angka ini sedikit lebih dari cakupan ASI eksklusif yang ditetapkan oleh kementerian kesehatan yaitu $50 \% .{ }^{16}$ Walaupun angka ini berada di atas angka 
nasional, tetapi berada di bawah target Kota Padang.

Berdasarkan penelitian didapatkan pemberian ASI tidak eksklusif dan tidak ASI didapatkan sebesar $43,3 \%$ dan $3,7 \%$. Banyak faktor penyebab ibu tidak memberikan ASI secara eksklusif yang sangat dibutuhkan oleh anak. Diduga ibu tidak memiliki waktu yang cukup, pengetahuan ibu tentang pemberian ASI, dan masalah pengeluaran ASI. ${ }^{10}$

Hubungan riwayat pemberian ASI dengan kecenderungan ADHD pada anak diketahui melalui uji chi square. Hasil penelitian menunjukkan bahwa 11 orang (15,5\%) siswa dengan kecenderungan ADHD dengan riwayat pemberian ASI eksklusif dan 14 orang $(22,2 \%)$ siswa dengan kecenderungan ADHD dengan riwayat tidak diberikan ASI eksklusif dan tidak ASI. Berdasarkan analisis, didapatkan nilai $p=0,318$ ( $p>0,05)$ menunjukkan tidak ada hubungan yang bermakna antara riwayat pemberian ASI dengan kecenderungan ADHD pada anak. Hasil penelitian ini sejalan dengan penelitian Hadiati (2018) yang mendapatkan bahwa tidak ada hubungan antara pola menyusui ibu dengan ADHD. Hadiati menyebutkan bahwa ADHD terjadi pada anak dengan berbagai pola menyusui. ${ }^{7}$ Penelitian oleh Boucher et al di Spanyol (2017) juga menyatakan tidak ada hubungan signifikan antara lama durasi menyusui dan menyusui secara eksklusif dengan gejala atau kejadian ADHD. Namun, hubungan durasi menyusui yang lebih lama dikaitkan dengan perkembangan kognitif yang lebih baik dan sifat autism yang lebih sedikit pada anak. Hal ini menunjukkan bahwa ASI memiliki peran perlindungan terhadap sifat autism pada anak. ${ }^{25} \mathrm{Hal}$ ini juga sesuai dengan penelitian yang dilakukan Sari Bar et al (2016) menyatakan bahwa anak yang menyusui lebih dari 6 bulan memiliki hasil kognitif yang lebih baik dan risiko lebih rendah mengalami ADHD dan autisme. ${ }^{26}$

Hasil penelitian ini menunjukkan hal yang berbeda yang dilakukan oleh Zeng et al (2018) yaitu anak dengan tidak ASI eksklusif atau durasi yang menyusui singkat memiliki risiko ADHD yang lebih tinggi dibandingkan dengan menyusui secara eksklusif. Diduga perbedaan analisis membuat penelitian ini berbeda dari peneliti. ${ }^{27}$ Perbedaan hasil penelitian ini disebabkan oleh beberapa faktor lain yang mempengaruhi ADHD baik secara internal maupun eksternal. Stadler et al (2015) menyebutkan bahwa keterlibatan genetik dan lingkungan sangat mempengaruhi perkembangan saraf anak termasuk pada ADHD. ${ }^{10}$ Ini sesuai dengan penelitian yang dilakukan Park et al (2014) bahawa sekitar 75\% ADHD disebabkan oleh faktor genetik dan sisa lainnya dikaitkan dengan faktor lingkungan. ${ }^{12}$ Anak dengan ibu yang ADHD memiliki risiko lebih tinggi untuk juga mengalami ADHD. IQ anak yang lebih rendah akan cenderung meningkatkan risiko kejadian ADHD. Pada sebagian anak lamanya masa menyusui tidak menyebabkan ADHD, sedangkan untuk yang lain, itu mungkin merupakan risiko tambahan yang penting yang menyebabkan ADHD. Ibu tidak hanya mewariskan risiko genetik untuk ADHD kepada anak, namun juga membuat anak terkena faktor lingkungan baik sebelum dan sesudah kelahiran. Kontak antara ibu-anak pada saat menyusui juga menentukan hubungan munculnya awal risiko ADHD. ${ }^{10}$ lbu dari anak-anak yang mengalami ADHD kemungkinan juga mengalami ADHD sehingga mempengaruhi pada keterampilan menyusui yang tidak tepat atau tidak memadai. Riwayat BBLR juga meningkatkan risiko ADHD pada anak. Ini kemungkinan berkaitan dengan adanya minimal brain disorder yang banyak dijumpai pada anak yang BBLR. ${ }^{9}$

Stergiakouli (2015) meneliti bahwa peluang ibu yang merokok sebelum dan selama kehamilan trimester pertama, serta ibu yang tidak menyusui pada 2 bulan setelah kelahiran anak akan meningkatkan kejadian ADHD. ${ }^{28}$ Permasalahan pada saluran cerna anak juga mempengaruhi kejadian ADHD. Ini berkaitan dengan mikrobiota yang terdapat pada saluran cerna yang berfungsi sebagai neurotransmitter sebagai penyebab dari ADHD. Juga peningkatan insiden gejala gastrointestinal seperti konstipasi dan perut kembung pada anak ADHD. ${ }^{29}$ Meskipun demikian, pada penelitian ini dapat dilihat bahwa data anak ADHD yang mendapatkan ASI eksklusif mengalami gejala lebih sedikit dari pada anak yang tidak mendapatkan ASI eksklusif.

\section{SIMPULAN}

Tidak terdapat hubungan yang signifikan antara riwayat pemberian ASI dengan kecenderungan ADHD pada siswa SD di Kota Padang. 


\section{UCAPAN TERIMA KASIH}

Terima kasih kepada semua pihak yang memberikan arahan, bimbingan, serta motivasi terhadap penelitian ini.

\section{DAFTAR PUSTAKA}

1. Saputro D. ADHD (Attention deficit/hyperactivity disorder). Edisi ke-1. Jakarta: Sagung Seto; 2009.hlm.52-63.

2. American Psychiatric Association. The diagnostic and statistical manual of mental disorders. Edisi ke-5. Amerika Serikat: American Psychiatric Association; 2013.hlm.80-5.

3. Caci $\mathrm{H}$, Asherson P, Donfrancesco R, Faraone SV, Hervas A, Fitzgeral, et al. Daily life impairments associated with childhood/ adolescent attention-deficit/hyperactivity disorder as recalled by adults: results from the European lifetime impairment survey. Cambridge Journal. 2015;20(2):112-21.

4. Christina YM, Herini ES, Gamayanti I. Perbandingan faktor risiko gangguan pemusatan perhatian/hiperaktivitas di daerah pedesaan dan perkotaan. Sari Pediatri. 2013;15(4):225-31.

5. Sayal K, Prasad V, Daley D, Ford T, Coghill D. Review ADHD in children and young people: prevalence, care pathways, and service provision. The Lancet Psychiatry. 2017;0366(17):1-12.

6. Polanczyk G V, Willcutt EG, Salum GA, Kieling C, Rohde LA. ADHD prevalence estimates across three decades: an updated systematic review and meta-regression analysis. Int $\mathrm{J}$ Epidemiol. 2014;43(2):434-42.

7. Hadiati T. Hubungan antara pola menyusui lbu dengan gangguan ADHD pada anak. J Nutr Heal. 2018;6(1):17-20.

8. Novriana DE, Yanis A, Masri M. Prevalensi gangguan pemusatan perhatian dan hiperaktivitas pada siswa dan siswi sekolah dasar negeri Kecamatan Padang Timur Kota Padang Tahun 2013. Jurnal Kesehatan Andalas. 2014;3(2):141-6.

9. Adiputra IMS, Sutarga IM, Pinatih GNI. Faktor risiko attention deficit hyperactivity disorder (ADHD ) pada anak di Denpasar. Public Heal
Prev Med. 2015;3(1):43-8.

10. Stadler DD, Musser ED, Holton KF, Shannon J, Nigg JT. Recalled initiation and duration of maternal breastfeeding among children with and without ADHD in a well characterized casecontrol sample. J Abnorm Child Psychol. 2015; 00(00):1-9.

11. Cenit MC, Campillo I, Pilar N, Franch C, Dinan TG, Sanz Y. Gut microbiota and attention deficit hyperactivity disorder: new perspectives for a challenging condition. Eur Child Adolesc Psychiatry. 2017;00(00):1-12.

12. Park S, Kim B, Kim J, Shin M, Yoo HJ, Cho S. Protective effect of breastfeeding with regard to children's behavioral and cognitive problems. Nutr J. 2014;13(1):1-5.

13. Liu J, Leung P, Yang A. Breastfeeding and active bonding protects against children's internalizing behavior problems. 2014;6(1):76-89.

14. Mimouni-Bloch A, Kachevanskaya A, Mimouni BF, Shuper A, Raveh E, Linder N. Breastfeeding may protect from developing attentiondeficit/hyperactivity disorder. Breasfeeding Med. 2013;8(4):363-7.

15. Huang J, Peters KE, Vaughn MG, Witko C. Breastfeeding and trajectories of children' $s$ cognitive development. 2014;17(3):452-61.

16. Kementerian Kesehatan $\mathrm{RI}$ (Kemenkes RI). Situasi dan analisis ASI eksklusif. Kemenkes RI. 2014:01-06.

17. Dinas Kesehatan Kota Padang. Laporan cakupan ASI eksklusif. Padang; 2015-2017.

18. Fahriani R, Rohsiswatmo R, Hendarto A. Faktor yang memengaruhi pemberian ASI eksklusif pada bayi cukup bulan yang dilakukan inisiasi menyusu dini (IMD). Sari Pediatri. 2014;15(6):394-402.

19. Inayah G, Dian A. Determinan perilaku pemberian air susu ibu eksklusif pada lbu pekerja. Kesmas. 2013;7(7):298-303.

20. Danielson ML, Bitsko RH, Ghandour RM, Joseph $\mathrm{R}$, Kogan MD, Blumberg SJ, et al. Prevalence of parent-reported ADHD diagnosis and associated treatment among US Children and Adolescents. J Clin Child Adolesc Psychol. 2018;00(00):1-14.

21. Reale L, Bonati M. ADHD prevalence estimates 
in Italian children and adolescents: a methodological issue. Ital $\mathrm{J}$ Pediatr. 2018; 44 (108):1-9.

22. Ramy H, Sheikh M El, Sultan M, Bassim R, Eid $\mathrm{M}$, Ali R, et al. Risk factors influencing severity of attention deficit hyperactivity disorder in a sample of preparatory school students in Cairo. Clin Child Psychol Psychiatry. 2018;00(00):1-14.

23. Alzaben FN, Sehlo MG, Alghamdi WA, Tayeb HO, Khalifa DA, Mira AT, et al. Prevalence of attention deficit hyperactivity disorder and comorbid psychiatric and behavioral problems among primary school students in western Saudi Arabia. Saudi Med J. 2018;39(1):52-8.

24. Kaplan HI, Sadock BJ, Grebb JA. Sinopsis of Psychiatry. Edisi ke-2. Terjemahan oleh Widjaja Kusuma. Tangerang: Binarupa Aksara Publisher; 2010:744-53.

25. Boucher O, Julvez J, Guxens M, Arranz E, Ibarluzea J, Miguel MSD, et al. Association between breastfeeding duration and cognitive development, autistic traits and ADHD symptoms: a multicenter study in Spain. Pediatr Res. 2017;81(3):434-42.

26. Bar S, Milanaik R, Adesman A. Long-term neurodevelopmental benefits of breastfeeding. Dev Behavioeal Pediatr. 2016;28(4):559-66.

27. Zeng Y, Tang Y, Tang J, Shi J, Zhang L, Zhu T, et al. Association between the different duration of breastfeeding and attention deficit/ hyperactivity disorder in children: a systematic review. 2018;00(00):1-11.

28. Stergiakouli E. Shared genetic effects between clinical ADHD and smoking, alcohol and breastfeeding in mothers from the general population. World Congr Psychiatr Genet. 2015; 00(00):1-3.

29. Ming X, Chen N, Ray C, Brewer G, Kornitzer J, Steer RA. A gut feeling: A hypothesis of the role of the microbiome in attention-deficit/ hyperactivity disorders. Child Neurol Open. 2018; $5(1): 1-6$. 